\title{
Exposure and Health Impacts Related to Outdoor and Indoor Air Pollutants
}

\author{
Haider A. Khwaja
}

Citation: Khwaja, H.A. Exposure and Health Impacts Related to Outdoor and Indoor Air Pollutants. Atmosphere 2021, 12, 105. https:// doi.org/10.3390/atmos12010105

Received: 18 December 2020 Accepted: 8 January 2021 Published: 13 January 2021

Publisher's Note: MDPI stays neutral with regard to jurisdictional clai$\mathrm{ms}$ in published maps and institutional affiliations.

Copyright: () 2021 by the author. Licensee MDPI, Basel, Switzerland. This article is an open access article distributed under the terms and conditions of the Creative Commons Attribution (CC BY) license (https:// creativecommons.org/licenses/by/ $4.0 /)$.
Wadsworth Center, Department of Environmental Health Sciences, School of Public Health, University at Albany, Albany, NY 12222, USA; hkhwaja@albany.edu

The five papers included in this Special Issue represent a diverse selection of contributions. This Special Issue was aimed at researchers' expertise across scientific disciplines that investigate the exposure and health impacts related to outdoor and indoor air pollution with an emphasis on gases, particulate matter, organic and inorganic contaminants, and biological particles. The papers are organized as follows.

In the first contribution, $\mathrm{Li}$ and Friedrich [1] introduce a novel probabilistic methodology to simulate the life-long simultaneous exposure of $\mathrm{PM}_{2.5}$ and $\mathrm{NO}_{2}$ in European countries. Their method integrated indoor sources and other sources into traditional exposure models. This approach was applied to populations in the EU27 countries, as well as Norway and Switzerland. It was validated with measurement data adopted from the European multi-center study EXPOLIS. The results showed that the annual average exposure to $\mathrm{PM}_{2.5}$ and $\mathrm{NO}_{2}$ increased from the 1950s to a peak between the 1980s and the 1990s, showing a decrease until 2015 due to the implementation of a series of directives.

In the second contribution, Zhang et al. [2] presented air pollutant sources, chemical compositions, driving factors of particulate matter (PM) variations, and pollutant toxicity/health risks in subways. The global PM compliance rate of subways was found to be $30 \%$; pollution sources were mechanical wear and building material erosion. The authors discussed the problems and challenges during the deployment of air pollution governance.

In the third paper, Jiang et al. [3] validated a standard $k-\varepsilon$ model, which was used to investigate the effects of ground heating on ventilation and pollutant transport in a threedimensional (3D) street canyon. As the ground temperature increased, the contributions of air convection and turbulent diffusion to pollutant transport were determined. The pollutant concentrations inside the street canyon changes were discussed. The results demonstrated a good performance compared to previous studies' findings on a 2D street canyon flow and dispersion. The method used in this paper was helpful for pollutant transport investigations in urban areas.

Next, Hildebrandt et al. [4] investigated the condition of indoor air quality (IAQ) and the health of occupants in newly constructed high-rise apartments compared to traditional detached houses (Kampongs) in Surabaya, Indonesia. This study suggested major shortcomings in the indoor environment in newly constructed apartments for the physical and the mental health of occupants.

Finally, Ye et al. [5] provided general guidelines for residents about preventing mold growth in East Asia during the plum rain season. The study aimed to investigate the effects of human occupancy on indoor humidity and efficient relative humidity (RH) reduction methods to prevent mold growth in moist climates. The results showed that dehumidification and heating always reduced $\mathrm{RH}$ below the critical value under which mold growth could be inhibited. The effects of ventilation were found to be more sophisticated and depended upon human occupancy, outdoor air temperature, and air change per hour $(\mathrm{ACH})$.

The Guest Editor wishes to thank the editorial staff, particularly Ms. Elva Wang (Assistant Editor of Atmosphere) for providing the opportunity to edit this Special Issue. 
We would also like to thank the authors and reviewers who have critically evaluated the papers within a short period of time. Finally, we hope our readers will find this Special Issue useful and rewarding.

Funding: This research received no external funding.

Institutional Review Board Statement: Not applicable.

Informed Consent Statement: Not applicable.

Data Availability Statement: Not applicable.

Conflicts of Interest: The author declares no conflict of interest.

\section{References}

1. Li, N.; Friedrich, R. Methodology for Estimating the Lifelong Exposure to $\mathrm{PM}_{2.5}$ and $\mathrm{NO}_{2}$ - The Application to European Population Subgroups. Atmosphere 2019, 10, 507. [CrossRef]

2. Zhang, W.; Zhao, H.; Zhao, A.; Lin, J.; Zhou, R. Current Status, Challenges and Resilient Response to Air Pollution in Urban Subway. Atmosphere 2019, 10, 472. [CrossRef]

3. Jiang, G.; Hu, T.; Yang, H.; Friedrich, R. Effects of Ground Heating on Ventilation and Pollutant Transport in Three-Dimensional Urban Street Canyons with Unit Aspect Ratio. Atmosphere 2019, 10, 286. [CrossRef]

4. Hildebrandt, S.; Kubota, T.; Sani, H.A.; Surahman, U. Indoor Air Quality and Health in Newly Constructed Apartments in Developing Countries: A Case Study of Surabaya, Indonesia. Atmosphere 2019, 10, 182. [CrossRef]

5. Ye, J.; Qian, H.; Zheng, X.; Cao, G. Plum Rain-Season-Oriented Modelling and Intervention of Indoor Humidity with and without Human Occupancy. Atmosphere 2019, 10, 97. [CrossRef] 